\title{
Headteachers' Perception of the Implementation of the Capitation Grant Scheme In The Sunyani West District of the Brong Ahafo Region
}

\author{
Georgina Cate Foli * Mphil. Owusu Afriyie ${ }^{1}$ Med. \\ *Al-Faruk College of Education, Wenchi Brong Ahafo Region, Ghana-W/A \\ 1. Offinso College of Education, Offinso, Ashanti Region of Ghana- W/A
}

\begin{abstract}
This study was conducted to find out head teachers' perception of the implementation of the capitation grant scheme in Sunyani West East District of the Brong Ahafo Region. The study specifically focused on explaining how head teachers conceptualised the concept of capitation grant scheme, the implementation process, and the challenges associated with the implementation of the scheme. A descriptive research design was adopted for the study, and a questionnaire and an interview guide were designed and administered to a sample of 40 head teachers from the district in the Region. The analysis of data revealed that $70.0 \%$ of the head teachers had an in-depth understanding of the source of capitation grant as being from the Government. The study, among others, found that the main challenges confronting the smooth implementations of the scheme were delay in the release of funds and inadequate funds. It is recommended that Government should release adequate amount of the grant in good time (thus, before the beginning of each quarter) so that school heads will avoid pre-financing of school activities. Also, the Ghana Education Service should continue to train head teachers in financial management and administration for prudent use of funds.
\end{abstract}

\section{Background to the Study}

Educational financing has attracted the attention of every government that has ever ruled Ghana. Attempts have been made from the colonial periods to the present democratic era to ensure the expansion of educational facilities. These were made to ensure that children of school going-age gain free access to education. This is in line with the country's subscription to the MDGs (especially MDG 2) and also the 1992 Constitution. Historically, Graham (1971) states that as far back as 1852, an Educational Ordinance was passed by the Governor of Gold Coast to collect taxes for the provision of better education for the inhabitants of Her Majesty's Forts and settlement on the Gold Coast between 1891 and 1896. The Colonial government developed active interest in financing education in the Gold Coast.

The Ghana National Education Campaign Coalition and National Network for Education Development (GNECC \& NNED, 2006) also stated that in 1990, Ghana was among 155 governments in Jomtien, Thailand that promised 'Education for All' by 2000, a promise re-emphasised in Amman, Jordan in 1996 and in Dakar, Senegal 2000. This promise among others gave birth to Article 38 (2) of the 1992 Constitution of the Republic of Ghana which guarantees "all persons the right to equal educational opportunities and facilities". The constitutional provision provides that basic education shall be free, compulsory and available to all. This constitutional provision by the Government of Ghana in 1995, instituted the Free Compulsory Universal Basic Education (fCUBE) programme initially to be attained by the year 2005 (NNECC \& NNED, 2006).

It is the aim of the fCUBE to improve access to basic education, improves efficiency in management, improve the quality of learning and, in particular, address the gender disparity at the basic level (Asante, 2011). In spite of these ideals, the stark reality as at now is that the goal of universal coverage and free basic education remains implausible. Hence, the introduction of the capitation grant scheme by the Government of Ghana as part of the free Compulsory Universal Basic Education (fCUBE) policy which aims at increasing the participation of primary school going-age children so as to make it as close to one hundred per cent of the population as possible. The capitation grant scheme was piloted in the 2004/2005 academic year in some 
selected basic schools across the country and in all public schools in the 2005/2006 academic year (Maikish \& Geishberg, 2008; Nudzor, 2012).

The capitation grant scheme is basically a scheme in which every public primary school receives an amount of GH04.50 per pupil enrolled. The aim of the scheme is to remove any financial obstacles that might be created through the charge of levies as a means of raising funds, for example, for school repairs, cultural and sporting activities. These levies have the effect of deterring parents especially, the poor from sending their children to school in spite of the policy of fee-free tuition in basic schools.

The recent increased in the grant is to increase enrolment as well as improve upon teaching and learning in public basic schools. The scheme is a programmatic way of ensuring that financial obstacles such as fees and levies are removed so that all children will make themselves available for the service that the education system provides. The usage of the capitation grant has been designed to empower the schools to effectively and efficiently use the financial resources to plan and carry out school quality improvement activities. It is expected that the process of planning the activities will be participatory and transparent. Therefore, the grant is expected to serve as an opportunity to help build school level capacity to effectively implement fiscal decentralisation which is a long term goal of the government of Ghana (Asante, 2011). As a matter of fact, the report of the Core Welfare Indicators Questionnaire (CWIQ, 2003) showed a high rate of drop-out at the basic level of education. According to the report given, 25\% of children between the ages of 6-17 dropped out of school because of the cost of education. This obviously has dire implications for the achievement of the Millennium Development Goals (MDGs) one of which is to achieve universal primary education by the year 2015, Ghana National Education Campaign Coalition and Northern Network Education Development (GNECC \& NNED, 2006).

For the capitation grant scheme to be successfully implemented, it depends on the motivations and capacities of local leadership. Typically, the educational administrator can be said to be the one who provides formal leadership for an education which has due principal focus to improve teaching and learning. In order to carry out the administrative functions, a certain degree of authority is exercised over various are and operations. Good leadership is a very necessary prerequisite for achievement in any educational system. Louis and Miles ( 1990) came out with the argument that principals and head teachers need to manage, design and implement plans, and focus upon task achievement. They posited that principals and head teachers must deal with structures and systems, with the immediate future and status quo, and leaders who articulate vision, promote shared ownership and engage in evolutionary planning.

It is, therefore, necessary that the implementation of the capitation grant scheme have institutional leaders who have the right perceptions and the abilities to face and handle the challenges confronting the scheme. This kind of leadership will create an enabling environment for the school to run effectively to achieve the programme's objectives. Under the scheme, the head teachers are to ensure the effective utilisation of the capitation grants and also implement the activities as provided in the School Performance Improvement Plan (SPIP). Also, head teachers are to ensure proper accountability of all funds that are received and utilised in the schools.

Perception is very necessary because it is one of the starting points for all others psychological processes. It also gives the necessary data needed for learning and remembering, for thinking and problem solving for communicating with others, for experiencing 'emotions' and for being aware of oneself (Wortman, Luftos \& Marshall, 1992). Perception, therefore, drives the human beings in his actions and behavioural patterns. It is, therefore, necessary to emphasise that head teachers perception will determine their actions and behavioural patterns towards the implementation of the capitation grant scheme. If they have a positive perception about the scheme, they are likely to apply funds appropriately for the achievement of its aims and objectives. On the other hand, any misconception of the scheme by head teachers will spell doom for the scheme.

Before the implementation of the capitation grant in the Sunyani West District, the District Director of Education together with the four frontline Assistant Directors, the District Accountant, Budget Officer and one person from the District Assembly were invited to attend a workshop at Ajumako in August 2005 to brief them on the capitation grant scheme. They had the theme for the workshop being, "Ensuring Transparency and Accountability in the implementation of the Capitation Grant Scheme." When they returned, personnel the Regional Education Office organised a day's workshop for all the head teachers and the School Management Committee (SMC) Chairmen in the Sunyani West District on the scheme. After the workshop, the head teachers were made to open a saving account which was later changed to a current account by the District Education Office. The District Education Office, therefore, saw the need to retrain all 
the head teachers and their assistants at the various Circuit centres on the implementation of the scheme and the preparation of the School Performance Improvement Plan (SPIP).

The Assistant Director of Administration and Finance, and the Budget Officer now have the authority to withdraw all monies instead of the District

Director of Education and Budget Officer initially assigned to the task. The actual figure that is paid to each school per pupil is GH04.50. The reason is that GH01.50 pesewas are paid back to the District Education Officer (DEO) for sports and culture which takes 60pesewas and 45 pesewas respectively. The Sunyani West District Education Office in to pays about 40 percent of the total amount to the Brong Ahafo Regional Directorate of Education.

\section{The Free Compulsory Universal Basic Education (fCUBE)}

The programme has its focus on primary education and it seeks to improve upon the 1987 reform by addressing the shortcomings identified in the implementation process to insure quality education. It is also the aim of the programme to increase the participation of children who are of school going age so as to make it close to a hundred percent of the population. Also, the programme seeks to address a particular policy focus of raising the enrolment of girls especially in the basic schools. In 1984, Ghana embarked on major reforms after a period of sharp economic decline in the later part of the 1970s and 1980s that had contributed to the decline in the government's investment in education. The real value of government financing for education fell from 6.4\% of GDP in 1976 to $1.4 \%$ in 1983. This decline resulted in little supervision and inspection in schools and the neglect and abandoning of schools buildings, inadequate supply of textbooks and instructional materials (Korboe \& Boakye,1995).

Consequently, a committee was set up in 1994 known as the Education Review Committee which reviewed the Education Reform Programme and it revealed that while there had been expansion of access to basic education and increase physical output; these had not led to the improvement in teaching and learning in schools. In view of these facts, the government of Ghana introduced the fCUBE programme in 1996 (World Bank, 2004)

According to Osei, Owusu, Asem and Afutu-Kotey(2009), the fCUBE was set in fulfilment of the constitutional mandate of the Fourth Republic which states in Chapter 6 Section 2 as,

The government shall, within two years, after parliament first meets, after coming into force of this constitution, draws up a programme for the implementation within the following ten years, for the provision of free Compulsory and Universal Basic Education (Fcube).

Thus, the fCUBE programme is constitutional requirement to provide quality education to all children in Ghana within a stipulated time of 10 years. The programme is a reinforcement of the on-going educational reforms from the previous education reform programme in that it is;

1. A constitutional requirement.

2. Sector-wode and integrated in scope.

3. To reinforce the national decentralization policy by transferring ownership management and control education services and facilities to local level.

4. To achieve high level of equity and efficiency in the provision of educational service within a stipulated time.

A policy document for Fcube (1995) developed to guide the execution of the programme came out to address four main constrains to the provision of good quality Universal Basic Education in Ghana. The constraints are:

1. Poor teaching and learning resulting in poor performance of children throughout the basic education level.

2. Inadequate access to educational service,

3. Weak management capacity at all levels of educational system and

4. Unsatisfactory financing arrangement for the education sector.

An fCUBE implementation plan which adopts a range of strategies for achieving quality, efficiency and access to educational service has been developed. The policy document further states that the strategies revolve around three main components all geared towards the provision of full access to good quality basic education for all Ghanaian children. These components are as follows: improving access of participation (GES, 2005). 
Both the Centre for Research on Improving Quality of Primary Education (CRIQPEG, 1996) and Amanfo (2000) asserted that the Fcube programme suffers from a number of structural weaknesses in most of its policies, strategies and interventions. This tends to' the effectiveness of Ministry of Education and at the Ghana Education Service as providers and promoters of good quality education. However, there is most doubt that barring most of the expected problems, the lofty ideas enshrined in the fCUBE programme are not elusive but rather achievable. To speed up the realisation of the ultimate goals of the fCUBE programme, the Government of Ghana through the Ministry of Education and the Ghana Education Service introduced the capitation grant scheme. The Capitation Grant Scheme According to the Education Agenda, a publication of the Ghana National Education Campaign Coalition and Northern Network (GNECC \& NNED, 2006), the government own White Paper on the report of the President's Committee on the review of education reforms in Ghana in October, 2004, indicated that 'the survival rate from primary 1 to primary 6 has been only $80.6 \%$ for boys and $78.9 \%$ for girls. In other words, about 4 out of every 10 children enrolled at primary 1 drop out before completing primary education. Only three quarters of those who reach primary 6 proceed to Junior High School (JHS) and only $88.2 \%$ of this number complete JHS. However, to achieve the free compulsory Universal Education (fCUBE), this figure of survival needed to reach 100\%. The assigned reason for the dropout rate was that the parents could not simply pay for the levies charged by the schools. The Government of Ghana, therefore, set up a capitation grant scheme which was started in 2005/2006 academic year, whereby every primary school received GI-104.50 (per pupil enrolled). This was set to remove the financial barrier created by this levies. Earlier, government had made a pilot basic capitation grant in 40 deprived districts throughout the country during the 2004/2005 academic year whereby every primary school received an amount of GI-103.00 per male pupil enrolled and GI-103.50 per female pupil enrolled for minor repairs of school furniture, recreational facilities and provision of teaching and learning materials. Presently, the grant has been increased to GH04.50 per pupil enrolled in the primary school. According to the guidelines for the utilisation of the capitation grant to primary schools (GES, 2005), the capitation grant has been designed to empower the schools to effectively use financial resources to plan and carry out schools quality improvement activities. The process of planning activities is to be participatory and transparent. The grant is, therefore, expected to serve as an opportunity to help build school level capacity and to effectively implement fiscal decentralisation which is a long term goal of the Government of Ghana. The Capitation Grant Scheme is to cover all registered public schools in the Ghana Education Service in Ghana. The actual enrolment at the end of third term for the supervision year is used as the base and projected by an expected gross enrolment to get the estimated number of pupils to be used for budget purposes. The grants are to be used to support the implementation of school Performance Improvement Plans (SPIPs). The challenges in the implementation of the Capitation Grant Scheme according to the Northern Network for Education Development (NNED, 2007) are as follows:

The cumbersome procedure of administering the grant is hindering progress in the implementation of the Capitation Grant with the three northern regions of Ghana.

1. The exclusion of SMC and PTAs from being signatories to the school accounts has led to the frequent rivalries between the two power blocks in running of the school. The problem here is that while SMCs are not signatories to the accounts, they are supposed to be involved in the drawing of the SPIPs, a pre-requisite for the approval of the Capitation Grant.

2. Head teachers have to travel to the District Capital in order to submit their budget to the District Budget Officer who then receives and deletes some of the items. The process continues till the budget is approved.

3. The amount paid as bank charges (GH05.00) reduces the value of the money.

The above challenges have been a great hindrance to the implementation of the scheme. This has, therefore, caused many school heads continue running the administration of the schools haphazardly in spite of the advantages the scheme is to accomplish. According to the GNECC and NNED (2006), a research conducted in the Nkwanta District of the Volta Region, there has been an explosion in enrolment following the announcement of the capitation grant. The findings indicated that although the grant has increased the number of pupils in education, its quality could be compromised due to lack of teachers. As the pre-school level at Odom Challa, for instance, one teacher is said to be teaching 98 pupils. Some are compelled to sit on the bare floor due to inadequate furniture. The pupil-desk ratio was estimated at 3:1 (GNECC \& NNED, 2006). 
Similarly, the report also stated that textbooks were outmoded and even inadequate, as the pupil-textbook ratio was 1:3. The Kete Krachi District is equally experiencing short supply of textbooks as the Capitation Grant has sent more children to school. The schools were left with no option than to rely old stocks. Here, the ratio by textbook-pupil was 1:4. As a result teachers are compelled to write comprehension passages on chalkboards. At Kanease L/A Primary School also in Krachi, according to GNECC and NNED (2006), a teacher had about 104 pupils.

SEND Ghana (2010) and Asante (2010) also found in their separate studies that despite the capitation grant's noble objective to abolish fees and levies charged to parents to make public basic education free, this has not been the practice, particularly in urban areas. Most schools continue to charge parents on a voluntary basis, through their PTAs, for items not covered under the capitation grant. These include examination printing and stationery, security, sanitation, major repairs, utilities, emergencies, amongst others. Asante (2010) says that critics of the capitation grant argue that this strategy may not have the desired impact on the quality of education. The quick high increase in enrolment experience from most of the countries that have adopted the school fee abolition raises questions about its impact on the quality of education. It is argued that when classes become too large or overcrowded and resources (human and other educational resources) are not increased proportionately, the result can reverse hard-earned gains and de- motivate teachers, parents and pupils. Enrolling children in school is one thing, but keeping them there in attendance is the more important challenge. Furthermore, in most Sub Saharan African countries like Ghana, education quality is generally low to start with and any deterioration in the conditions of learning resulting from a surge in enrolment is likely to have a dramatic negative effect on completion and achievement.

The Ghana Education Service (GES, 2005) has indicated that the capitation grant scheme is not devoid of challenges. Some of the challenges identified by the GES include the following:

1. Increased demand for additional classrooms,

2. Demand for additional teachers,

3. Demand for additional textbooks and other teaching and learning materials,

4. Difficulty of sustaining community participation,

5. Revision of the capitation grants and proportion between Kindergarten, Primary, J SS or between boys and girls,

6. Even though actual release of funds has been smooth and effective, timely release of funds to districts and schools remains an issue,

7. Inadequate level of transparency at school level.

During a participation workshop in 2005, to discuss key issues and challenges in the educational system, GNECC and NNED (2006) arrived at a consensus that judging by the confusion that has arisen as a results of the capitation grant, there is therefore the urgent need for the government and stakeholders to engage in intensive public education on what the concept is all about. Public education, according to GNECC and NNED (2006), would make it possible for bureaucrats to be held accountable for any lapses in its implementation. Notwithstanding the above challenges, UNICEF (2007) reports that the decision to replace school fees with capitation grants has yielded some dividends by impacting positively on many enrolmentrelated figures during the 2005/06 school year. Some of the benefits are as follows:

1. Primary school gross enrolment rose by nearly 10 per cent, bringing total primary enrolment to 92.4 per cent nationwide. Primary net enrolment increased from 62 percent to 69 per cent.

2. Every region in the country experienced a rise in enrolment; Northern Region (where rates were lowest) experienced the largest increase.

3. Overall enrolment in basic school increased by 16.7 per cent in the 2005/06 school year compared to 2004/05. Enrolment of girls increased slightly more than that of boys (18.1 per cent vs. 15.3 percent).

\section{Financing Basic Education}

Education financing has attracted the attention of every government that has ever ruled Ghana. Attempts have been made from the Colonial period up to the present democratic era to ensure that the children of school going age gain free access to education. Graham (1971) contends that as far back as 1852, Educational Ordinances were passed by the governor of Gold Coast to collect taxes for the provision of better education for the inhabitants of her Majesty's Forts and settlement on the God Coast. He also stated 
that between 1891 and 1896, the colonial government developed active interests in financing education in the Gold Coast. He recounted that between the periods stated, government's expenditure on education moved from $£ 1,673,000$ to $£ 4,346,000$.

Efforts by government to provide education for children of Gold Coast continued as the need to develop the manpower of the colony through education was realised. The 1951 Accelerated Development Plan came to boost the effort of the governments. The plan had the view of tuition-free elementary education for children between the ages of six and twelve (Abosi \& Brookman-Amissah, 1992). The effort to provide free access to education continued when Ghana gained her independence. The 1961 Education Act was introduced by Dr. Kwame Nkrumah to legalise the 1951 Accelerated Development Plan. The act made primary and middle school free and compulsory. When Dr. Nkrumah's government was overthrown, the compulsory aspect of primary and middle school was removed. However, the free-tuition was maintained by the military government.

The 1992 Constitution of the Republic of Ghana also emphasised the provision of free Compulsory Universal Basic Education (fCUBE) for every child who has attained the school going age. Chapter 6 Article 38 Sections 2 of the 1992 Constitution states that the government shall within two years after parliament first meets after coming into force of this within the following ten (10) years, the provision of free Compulsory and Universal Basic Education. By the demand, the government needs to put in place a comprehensive programme to ensure that all children of Ghana who have attained the school age get easy access to basic education. A ten year grace period was given from 1995 to 2005 for full implementation of the fCUBE programme in accordance with the 1992 Constitution (Osei et al., 2009).

Several programmes were put in place to expand educational facilities in terms of establishing schools, such as building more classrooms, quality training of teachers, introduction of allowances to Teachers' Training Colleges, now Colleges of Education as incentives to encourage more people to train as teachers, promotion of community participation in school administration by the establishment of School Management Committees (SMCs) and training of head teachers in school administration. Some of the sources also from which basic education is funded from the Ghana Government sources, the Ghana Education Trust Fund (GET Fund), and the District Assemblies Common Funds. Highly Indebted Poor Country (HIPC) and debt forgiveness, community funding such as levies paid by the community members, Oturnfuo Education Fund and internally generated funds. The funds that the government provides make $89 \%$ of the total expenditure on education consisting of funds from the District Assemblies, the Ghana Education Service.

\section{Sources of School Funds}

According to Owusu as cited in Salamat, 2007), funds for the activities of the school come from various sources:

1. Financial contributions from chiefs and members of his community in which the school is located,

2. District Assembly Common Fund,

3. Fund raising activities by the school,

4. Cash Donations by old students

5. PTA levies,

6. Paying of extra classes fees to teachers by parents, etc.,

Normally the Central Government makes variety of financial provisions to the schools in the form of:

1. Payment of salaries of teachers and non-teaching staff

2. Payment towards the construction and maintenance of pavilion in some cases.

3. Payments of sports, cultural fees, etc. through quarterly grants.

The government's grants and fees collected from parents are normal sources of funding available to the school. The head has to explore other avenues for funding. Generally speaking, every institution, be it public or private, needs some amounts of funds which may not be contrary to government's regulations, thus, the Financial Administration Act 654 and Public Procurement Act 663 which restrict the extent to which schools may raise funds. Some of the sources include, funds from the floating of shares, loans, grants form Government, ploughing back profits and others from donor and non-governmental organisations (NGOs). Some of these sources are reliable whilst others are not. Commonwealth Secretariat (1993) has enumerated the various sources of funds which may be available to schools. This is an ample testimony that education is 
one of human institutions which needs huge sums of money to finance. These sources of funds has been classified into three major categories namely, Government (direct and indirect), Parents and the community groups, donor agencies/Non-Governmental Organisations and students and pupils.

It is an indisputable fact that the government of Ghana was, is and will always be the greatest contributor to education funding. Statistics available shows that the percentage share of education budget out of the National Budget also known as financial availability percentage rose from $21.95 \%$ to $32.60 \%$ in 1990 . In 1992, the total budget to the education sector alone was GHC580 million and this rose to GHC3,110 million in 1995. Similarly, records from the Ministry of Education (MOE) show that over the past decades, 40 percent of government's discretionary budget was allocated to education (Effah, 2003).

He again posits that the direct Government funding involves paying of salaries of teaching and non-teaching staff, financing construction and rehabilitations of school plant like buildings, workshops and offices. Statistics available shows that by the year 2000, the government was spending over $40 \%$ of its recurrent budget on education with $65 \%$ going into basic education. Government funding of education in the country involves training teachers, preparing curriculum/syllabuses, and assisting schools to establish money generating projects - through the provision of technical assistance.

Another source of funds for the school is the parents. Despite the inception of the fCUBE policy of free basic education, parents are required to make some financial contributions towards the school's development. This includes SMC/ PTA, District Assembly Unit Committee levies, and fees approved by GES from time to time. The community also provide land communal labour which when quantify in financial terms may be very substantial. The District Assembly spends much money on the construction, purchasing of equipment, furniture and other school items for both JHS and SHS. A case in point is the building of a 10 unit classroom storey building for Sefwi Bekwai SHS in the Bibiani Anhwiaso by the Bekwai District Assembly.

Local-based, national-based and international donor agencies and Non-Governmental Organisations operating in the country also contribute immensely towards the provision of education in the country. Major agencies/NGOs related to the provision of education in Ghana include the Adventist Relief Agency (ADRA), the Catholic Relief Services. World Vision Internationals, the Kristo Asafo Movement, Oxfam Action Aid, (Ghana), United States International Development Agency (USAID), the British Council, United Nations Children and Education Fund (UNICEF), Canadian International Development Agency (CIDA) and Sasakawa. Students or pupils are also a source of fund raising for their activities like farming, keeping poultry and pigs, making crafts, distribution of fund raisings cards or envelopes. At the basic level, source of funds are not as many as that of the second cycle institutions.

\section{The Concept of Financial Administration}

Managing funds is a very vital component of the broad field of school administration. Among other things, school financial administration determines the availability of facilities that are very much needed to enhance the process of teaching and learning. Therefore, it constitutes an area that demands the attention of education researchers. It is therefore, important that all school heads have sufficient knowledge of the concept Financial Administration' to be effective financial managers.

However in Ghana, school financial administration is an area within the education sector that has not been given the much needed attention. The result has been the inadequate scholarly literature on the raising and utilisation of funds by schools in the country. The better understanding of the concept financial administration will go a long way to enhance the efficiency and effectiveness of heads of school in the field. According to the Commonwealth Secretariat (1993), the concept financial administration entails a wide range of activities which involve identifying sources of funds, budgeting, securing the funds, recognising and practices governing and receiving, keeping and spending of funds. This presupposed that the head at the helm of financial administration has a lot of challenges that may impact negatively on the performance of his or her task. The Ghana Education Service echoed that a head of an institution is responsible through the Board of Governors to the financial administration of that institution (GES, 2005). The policy guideline of financial administration postulated by the Commonwealth Secretariat and GES require heads with knowledgeable skills, attitudes and values in accounting practices to execute their functions judiciously as financial administrators. This phenomenon attracted the attention of the World Conference on Education for all in Jomtien, Thailand in 1990. It was at this World Conference on Education where ministries, international agencies and NGO's agreed upon action plans to improve the capacity and financial 
performance of schools. The plans recognise that the school head carries prime responsibility for creating an effective educational environment, and without the needed skills, many heads are overwhelmed by the task of financial administration. The scopes of financial administration in schools need a lot much of commitment on the part of heads of schools. Heads must be well informed about the various sources of funds and their accessibility when the need arises.

Also, according to the GES directives, school heads should be prepared to be equipped with necessary administrative procedures involved in planning for the use of the funds and the necessary legislation in their spending and accounting procedures. Heads in Ghana are also responsible through the Board of Governors to the Ministers of Education for the financial business institutions. Among other things, the head is required to perform the following duties:

1. Ensure that proper account books of account and record relating thereto are kept;

2. Ensure that proper quarterly and annual accounts are prepared;

3. Make sure that all Audit Reports and quarries are promptly considered and replied to;

A critical analysis of the financial duties outlined above suggests that the issue of managing school funds is very crucial to school headship. Unfortunately some heads, especially those who operate at the basic level, sometimes fumble when they are confronted with issues related to school funds. Understanding the concept and nature of school financial administration as well as rules governing it is, therefore, very essential in the financial administration task of the head. In pursuance to the financial administration task, the head of an institution should have the assistance of his chief technical officer, the bursar and the other accounting staff in financial and accounting matters. Although the afore-mentioned situation is applicable to Senior High Schools, Colleges of Education, District Education offices and Education Units, it tells about the enon-nous responsibilities on the heads of Junior High Schools, who assume both financial and administration of their respective school without any technical officers to give them the needed advice. This suggests that heads of basic school even need much financial administration and management as compared to their counterparts in the Senior High School and Colleges of Education levels to enable them face challenges that they might encounter in handling the capitation grants.

\section{Challenges Related to Financial Administration in Schools}

In recent years, there has been a growing national concern over financial administration in public schools in the country. This is because most times heads refuse to involve of staff in financial matters; leading to disagreements and backbiting among staff. This ultimately has dire consequences on teaching and learning in schools. In the first instance, heads of these institutions have persistently complained about shortage of funds for running the schools. The funds made available to the schools, particularly for the purchase of teaching and learning materials like chalk, and exercise books are said to be woefully inadequate while the payment of the little that is given has often been unduly delayed. Inadequate funds to run the schools have led, on many occasions, to shortened school terms through earlier postponement of dates for re-opening or pre-mature closure of schools. Others include lack of fiscal control measure on the part of the heads as well as inadequate technical know-how on the part of the financial administrators. From the foregoing discussion, it is evidently clear that there is bound to be many challenges relating to financial administration in schools. Amofa-Kr (1988) conducted a study entitled "Personnel Participation in School Financial Administration: The case of Public Boarding Secondary Schools in the Cape Coast Municipality of Ghana," and came out with the following findings:

1. All the school personnel including the Heads or Bursars shared the view that heads as financial administrators need some basic knowledge in accounting and financial administration.

2. Heads of schools investigated have had no training in accounting and financial administration. Two disciplines above were considered necessary to Heads of Financial administration. It was also evident in the study that when those heads were Assistant Heads, they did not have access to much needed practical exposure to financial administration from their Heads. Obeng (2004) also conducted a study on the topic "Problems of Managing Finances at Antoa Senior Secondary School." In the study, the researcher used the Headmaster the Bursar and eight (8) accounting staff as the population and sample. He found that:

1. Heads lack basic accounting knowledge and most Bursars lack the requisite accounting qualification to manage school funds. 
2. Most heads were and still are Historians, Geographers, Science Tutors and most Bursars were still holders of the RSA Stage 3 in accounting as professional qualification. The deduction from the above for this study is that for effective financial administration and management in school (at all levels) requires well-trained personnel in this field. The Ghana Education Service must be taken a considering this especially for heads in basic schools in the country.

Another study pertaining to financial administration in Senior High Schools was conducted by TweneboaKodua (as cited in Salamat, 2007). The study was on the topic "Problems affecting Funds Management by Heads in Senior Secondary Schools in Oda: A case study of St. Francis Secondary Technical School at Oda in the Birim South District of the Eastern Region of Ghana." The findings of this study clearly revealed that embezzlement of school funds in Ghana, particularly in the second cycle institutions has been a great concern. The study dealt with the possible causes of problems of embezzlement of school funds and suggested possible solutions to them.

It was evident from the findings that there were other problems faced by the heads in financial management in second cycle institutions like students' debts, to level of accounting background of most heads, lack of trusts in accounting and purchasing officials and also level of qualification acquired by bursars. This makes it difficult for most heads to come out with a good and effective management of finance reports that are presented to the auditors.

A more related study in financial administration was conducted by Narh-Saam (2004). The study on the topic: "Financial records Keeping Practices of Heads of Basic Schools in the Birim South District" came out with the following findings:

1. Financial records keeping in the 1950s was not an official responsibility or duty of the basic school heads. This situation arose largely because logistics and any other items needed by the schools were supplied by their local and district councils, foreign and local donors. The basic school heads rarely handled money.

2. For accountability, transparency and fairness to prevail in school administration and management it has not only become necessary but mandatory for basic school heads to keep proper books of accounts. The realisation of these are almost becoming a mirage as just a few basic schools had the requisite knowledge in accounting and as a result a significant number of the heads could not keep any records on their financial transactions.

3. The basic school heads do not have account clerks to assist them in preparing their annual financial reports.

4. The study further indicated that only those who studied Accounting as a subject in schools or elsewhere were capable of keeping proper financial records. The study again showed that inservice courses organised for

Basic School heads, particularly those on financial records keeping were really useful to them and had improved their tasks as school administrators. The heads would, however, like these workshops to be organised regularly, at least once in every academic year.

5. School audits, the research revealed, were beneficial to the basic school heads as they were afforded the opportunity to have encounter with seasoned/experienced auditors who identified their weakness. The audits built up confidence in the stakeholders of education as they were satisfied that the funds they provided were properly kept and disbursed in line with the laid down procedures.

6. The heads of basic schools, the study revealed were solely responsible for the collection of approved fees from pupils or students and issued genuine receipts for all payment.

7. The standards of book keeping in the basic schools were low. The fact as previously established was due to the fact that majority of the Heads did not have adequate exposure to keep proper financial records.

8. The study also establishes the fact that the main sources of funds for running the basic schools were government approved fees and Parent-Teacher Association (PTA) dues and levies.

9. The common books of accounts used by basic school heads were cash books and receipt books. stud finally ascertained the fact that many of the basic school heads

10. They could not prepare their annual financial reports, but relied on staff members, auditors, friends and relations. However, those heads who had some knowledge in principles of accounts kept better records and needed little supervisions from the auditing team. 
Although these studies were conducted elsewhere, it appears that the challenges facing financial management in basic schools such as those in the Sunyani West District of the Brong Ahafo Region are similar. Clearly, there could be general challenges, facing financial administration in second cycle Schools, those challenges are likely to face the JHS heads as well. Hence, this study hopes that the observations and suggestions made in the above studies would corroborates (or otherwise) those to be established by this study.

\section{Auditing of School Accounts}

Raffa (2003) defines auditing as "an independent examination of an expression of opinion on the financial statement of an enterprise by an appointed Auditor" (p. 2). In pursuance of this appointment and in compliance with relevant statutory obligation, an in-depth understanding of the definition of auditing could be ascertained if the key words could be explained further.

1. Independent: The person who conducts the audit should be different from those who write the account books. The Auditor must be independent in mind and in person. This is a professional person who is unbiased in mind and in person. Unbiased in mind means he should be honest and in person means that he should not be in touch with the client.

2. Examination: It involves thinking through figures (thus figures do speak), verification of figures, scrutinising in such detail and interpreting them as will enable the auditors to form an opinion as to their truth and fairness. In other words, the books of accounts are subjected to scrutiny in detail by the Auditor in order to arrive at an opinion.

3. Expression of Opinion: The person who expresses his opinion must be an identified person accepted by his group (profession) and must have the requisite qualification and skill. He must have a profession and an expert and whatever decision he gives must be accepted. The opinion that he expresses on the account is true and fair view or not. This opinion adds credibility to these accounts of the enterprise. The true and fair view implies that the account do not contain any material errors and that they comply with the following principles:

a. Generally Accepted Accounting Principles (GAAP).

b. Local inter-related standards.

c. The laws of the land company code 1963 Act 179 .

d. Financial statements: These are profit and loss Accounts/Income and Expenditure Accounts for each accounting period.

e. A balance sheet as at the accounting reference date. f. Sources and application of funds (funds flow statement).

f. Notes attached to and forming part of the accounts.

g. A director's report.

The above principles should be abided by even basic school heads if the capitation grant scheme was to be managed effectively and efficiently to achieve its full objectives.

\section{Summary of Review}

Improving educational access in Ghana has moved through several paths and currently with the introduction of capitation wants to eradicate fees in basic schools. The principle behind introducing capitation was that it would eliminate household need to pay fees for basic education, especially for the poor who it had been shown were not accessing education because of the costs, and enable schools to use the funds to improve the quality of education. The literature reveals some financial administration and management challenges that the scheme faced in these few years of its introduction. The challenge of delayed and inadequacy of the grants. Despite the above challenges, according to Ghana's EMIS data after CGs had been introduced, basic school enrolments increased by an estimated 17\% (MESS as cited in Akyeampong, 2011). The perceptions and capacities of school heads in implementing the capitation grant scheme is very important.

\section{Research Design}

A descriptive survey was adopted for the study. This is because it affords the opportunity to select a sample from the population being studied and make possible, generalisations of the sample being studied. Babbie (1992) stated that descriptive surveys are excellent means of measuring attitude and orientations in a large population and they allow the researcher the opportunity to ask many questions on a given topic, thus giving 
enough flexibility in his analysis. It focuses on vital facts about people and their beliefs, opinions, attitudes, motivations and behaviours and simply describes and provides understanding of a phenomenon. Furthermore, it provides information on what to base sound decisions. Osuala (2005) says descriptive survey interprets, synthesises and integrates data and points to implications and interrelationships. Also, in-depth follow up questions can be asked and items that are unclear can be explained using descriptive design (Fraenkel \& Wallen, 2000).

Peil (1995) indicated that descriptive surveys can provide reliable valid and theoretical meaningful information. She further observes that descriptive surveys make useful contributions to theory, and provide up to date information on policy-related issues. Peil further argues that descriptive surveys combine both qualitative and quantitative methods. She says any distinction between the two is artificial since survey take into account how much and how often phenomena happen. These reason informed its appropriateness to this study since the research involved collecting data in order to answer questions concerning the perceptions of basic school heads on the implementation of the capitation grant schemes in the Sunyani West District of the Brong Ahafo Region.

Descriptive survey involves the collection and interpretation of data (Best \& Kahn, 1995). Descriptive survey have population validity; that is survey research uses questionnaires or structured interviews with the aim of making a generalisation from a sample to a large population. By asking a good number of questions, it is possible to get broad and accurate view of response to certain issue and to test theories on social relationship (Babble, 1992; Gill \& Johnson, 1991). Survey research is used to influence policy makers, especially government on policies, revising or improving upon existing conditions. It also provides useful suggestion for addressing undesirable social development. Mitchell and Jolley (2004) say descriptive survey is simple and easily applicable to all social problems, especially on our part of the world. Thus, collecting data to answer head teachers perception and challenges in implementation of the capitation grant scheme falls within the descriptive survey.

\section{Population}

The study was carried out in the Sunyani West District also called the Odurnase District has a total number of 127 schools made up of 32 kindergartens, 53 primary schools and 42 Junior High Schools. The targeted population for the study comprised all head teachers in public basic schools in the District.

\section{Sample and Sampling Procedure}

In all, a sample size of 40 was determined. This was in line with the proposal by Osuala (2005) that for a few tens and hundreds of population, at least 30 respondents was representative. On the selection of the head teachers, the register for the Sunyani West District was compiled and fed into the SPSS, where the Random Number Generator was used to select 40 respondents. This procedure was adopted with the aim of making sure that representative samples were chosen for the study.

\section{Research Instruments}

The questionnaire and interview guide were designed for the respondents. The design of the questionnaire and interviews were guided greatly by the research questions in the study. The questionnaire and interviews offered the respondents complete anonymity and gave enough time to reflect over the questions to enable them give more meaningful answers. The questionnaire and interviews consisted of five section: the first solicited information on background information of the head teachers. Second question was based on how head teachers perceived the implementation of the scheme in the Sunyani West District. The questions included the understanding of importance of the scheme and they perceived to be the important of the scheme. The third section of the questionnaire was also about the capitation grant scheme. The section sought to gather responses as to head teachers' influence on the implementation scheme. Section five sought to find out how head teachers perceive the challenges associated with the implementation of the scheme and the final section looked at the extent to which head teachers were capable of facing possible challenges. In all, there were 24 items on the questionnaire. The interview guide also had five sections.

\section{Data Collection Procedure}

I collected a letter of introduction from the Director of the Institute of Educational Planning and Administration (IEPA), University of Cape Coast, and this was shown to the District Director of Education 
and the various head teachers of the selected schools. I contacted the respondents personally and gave out copies of the questionnaire and expressed the importance of the exercise to them. The questionnaires were collected a week after the distribution. This was to give enough time to the respondents to thoroughly respond to the questions.

\section{Data Analysis Procedure}

The data was analyzed descriptively according to the research questions by the use of frequencies and percentages. Percentages have the advantage of making findings known to a variety of people who need to be informed. Tables were also used to enhance the understanding of the data. The study used the Statistical Package for the Social and Sciences (SPSS version 17.0), a computer software, to analyse the data gathered.

\section{Results and Discussion}

This chapter presents the result obtained from the study on the perception of head teachers on the implementation of the capitation grant scheme. The study specifically dealt with the following research questions:

1. How do head teachers construct the concept of capitation grant scheme?

2. How do head teachers perceive the implementation of the scheme in the Sunyani West District?

3. What challenges are associated with the implementation of the scheme?

Data were gathered from 40 head teachers in the Sunyani West District. The study used descriptive statistics including tables, frequencies and percentages to address the research questions posed.

\section{Background Information of the Respondents}

The study considered it as important the background information of the respondents of the study. Therefore, questions were asked to obtain these data and these responses are presented in Tables 1 to 3 and Figure 1. The data gathered on the gender and age distribution of respondents are contained in Table 1.

Table 1: Gender and Age Distribution

\begin{tabular}{|l|llllll|}
\hline & \multicolumn{3}{|c|}{$\begin{array}{l}\text { Gender } \\
\text { Male }\end{array}$} & \multicolumn{3}{c|}{ Total } \\
\hline Age (in years) & No & $\%$ & No & $\%$ & No & $\%$ \\
$20-30$ & 0 & 0.0 & 0 & 8.6 & 0 & 0.0 \\
$31-40$ & 5 & 13.1 & 0 & 13.0 & 5 & 12.5 \\
$41-50$ & 21 & 55.3 & 0 & 43.5 & 21 & 52.5 \\
$51-60$ & 12 & 31.6 & 2 & 34.9 & 14 & 35.0 \\
Total & $\mathbf{3 8}$ & $\mathbf{1 0 0 . 0}$ & $\mathbf{2}$ & $\mathbf{1 0 0 . 0}$ & $\mathbf{4 0}$ & $\mathbf{1 0 0 . 0}$ \\
& & & & & & \\
\hline
\end{tabular}

Table 1 shows that overwhelming majority $38(95.0 \%)$ of the head teachers were males, while the remaining $2(5.0 \%)$ of them were females. Again, the modal age bracket of the respondents was 41 to 50 years with all being males. The only two headmistresses were at least 51 years. Generally, the respondents were old. The study considered it necessary to know the marital status of the participants since this could affect their handling of funds. Figure 1 displays the data collected from the respondents. 


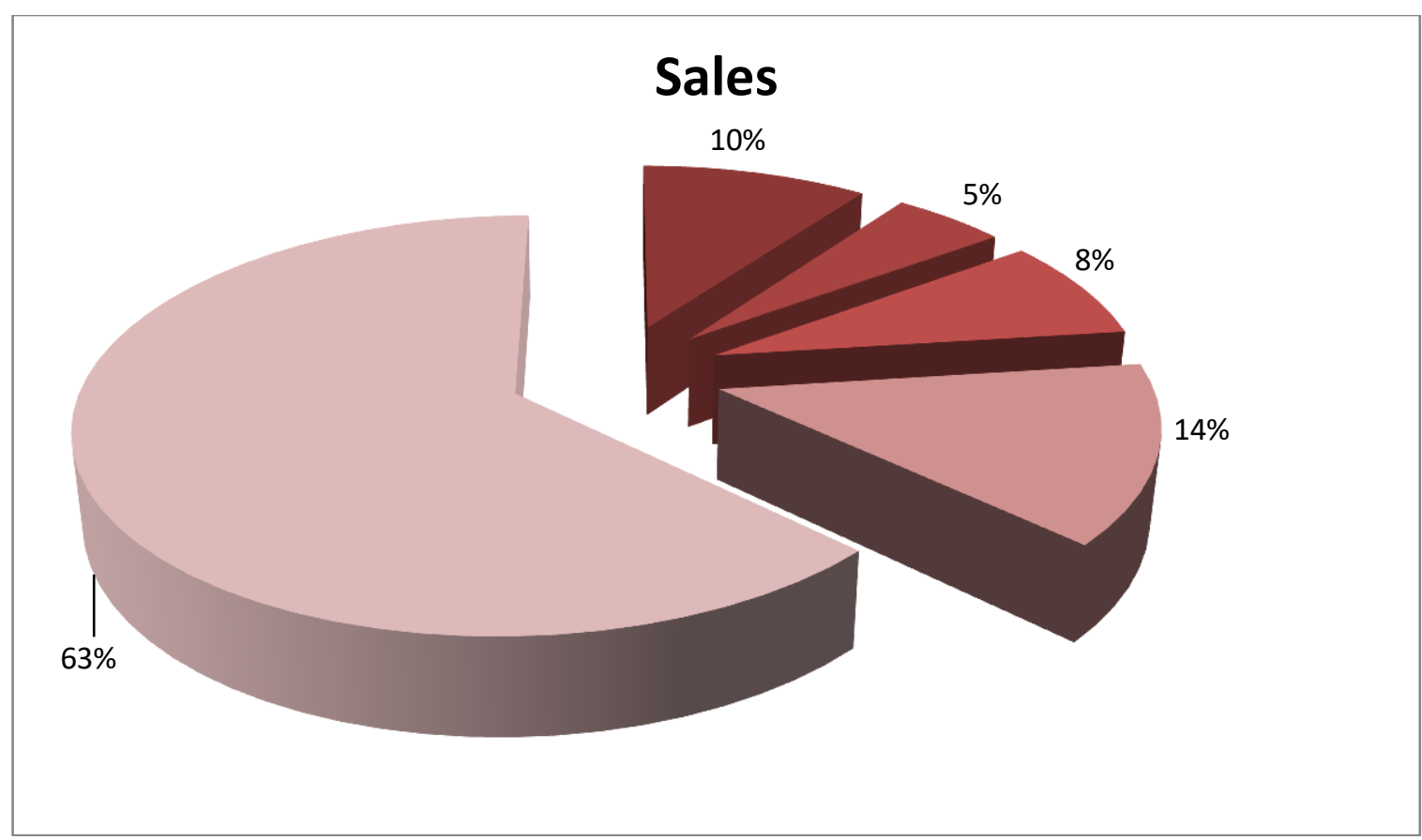

Figure 1: Marital Status of Respondents

It can be seen from Figure 1 that rnajority $63 \%$ of the teachers were married, single (14\%), while the remaining of them were once married but unmarried now because of reasons like divorce, separation and death of one spouse. Findings showed that majority of the respondents were married. Again, on the qualifications of the respondents, the study asked the head teachers to indicate their highest professional qualifications. Responses are tabulated in Table 2.

Table 2: Highest Professional Qualifications of the Head teachers

\begin{tabular}{|l|l|l|}
\hline Qualifications & Frequency & Percentage \\
\hline Cert 'A' & 5 & 12.5 \\
Specialist & 2 & 5.0 \\
Diploma & 8 & 20.0 \\
Bachelor & 20 & 50.0 \\
Masters & 5 & 12.5 \\
Total & $\mathbf{4 0}$ & $\mathbf{1 0 0 . 0}$ \\
\hline
\end{tabular}

From Table 2, half $(50.0 \%)$ of the heads had obtained Bachelor degrees in various fields of training such as B.Ed, B.A., B.Sc., etc., while 5 (12.5\%) each had Master's degrees and Certificate 'A' and Diplomas. Only $2(5.0 \%)$ of the respondents had Specialist, and 8 (20.0\%) had Diploma. It emerged that almost all the respondents were professional teachers.

On the duration of service of respondents, Table 3 summarised the data. There were three options: "not more than 10," "11-20" and "At least 21 " years.

\section{Table 3: Duration of Service as Head teachers}

\begin{tabular}{|l|l|l|}
\hline Duration (in years) & Frequency & Percentage \\
\hline At most 10 & 27 & 67.5 \\
$11-20$ & 10 & 25.0 \\
21 and above & 3 & 7.5 \\
Total & $\mathbf{4 0}$ & $\mathbf{1 0 0 . 0}$ \\
& & \\
\hline
\end{tabular}

Majority $(67.5 \%)$ of the head teachers had served as head teachers within 10 years, while $24 \%$ of them had been in such position for $11-20$ years. Only about three $(7.5 \%)$ of the head teachers had served at least 21 years. It can be inferred that these sampled head teachers have considerable experience tin handing financial 
administration of the capitation grant. From the background information of the respondents, $87.5 \%$ of them were aged at 41 years. Agen, $62.5 \%$ had at least first degree, while all of them had served as head teachers for many years. These findings show that the head teachers were well-experience enough in issues bout the capitation grant scheme which was fully implemented in 2005. Again, this group of head teachers are also in a better stead to provide adequate and relevant information on the topic as stake.

Research Question 1: How do head teachers construct the concept of the capitation grant? The study sought to bring to the fore the understanding of the head teachers about the Concept of capitation grant scheme. It explored the advantages of the scheme, reasons for its introduction, and the kind of in-service training provided for head teachers. Table 4 summarised the head teachers' understanding of the scheme.

\section{Table 4: Head teachers' Understanding of Capitation Grant Scheme}

\begin{tabular}{|l|l|c|}
\hline \multicolumn{1}{|c|}{ Meaning } & Frequency & Percentage \\
\hline PTA dues & 13 & 20.0 \\
Sales from school farm & 1 & 5.0 \\
Levies from pupils & 1 & 5.0 \\
Grant from Government & 25 & 70.0 \\
Grant from donor agencies & 0 & 0.0 \\
Total & $\mathbf{4 0}$ & $\mathbf{1 0 0 . 0}$ \\
\hline
\end{tabular}

Table 4 showed that majority $(70.0 \%)$ of the head teachers confirmed that capitation grants is "the money that the Central Government releases to basic schools for day-to-day running of schools." Thirteen representing $20.0 \%$ claimed that dues from the PTA served as capitation grant. Two constituting $10.0 \%$ of the head teachers indicated that monies from the sales of school farm produce and levies collected from pupils were termed as capitation grant. As far as grants from donor agencies were concerned none of the heads considered it as the meaning of the grant. It can be concluded that majority of them really understood what the capitation grant scheme meant to be used for. This was confirmed in interviews with head teachers who said: the capitation want is given out by the government and its purpose is to provide facilities that will enhance teaching and learning in the schools. This grant is therefore given out to schools at the beginning of each term.

Table 5: Advantages of the Capitation Grant Scheme

\begin{tabular}{|l|l|l|}
\hline & Frequency & Percentage \\
\hline Responses & 3 & 7.0 \\
Money needed is granted & 1 & 3.0 \\
Needs of school catered for & 0 & 0.0 \\
Increase in levies & 36 & \\
Parents less burdened & 90.0 & $\mathbf{1 0 0 . 0}$ \\
Total & $\mathbf{4 0}$ & \\
\hline
\end{tabular}

Table 5 revealed that $36(90.0 \%)$ respondents indicated that the capitation grant had helped lessened the burden on parents and $3(7.0 \%)$ of the respondents also stated that with the grant, money needed for running the school was released. Hence, it was nobody's headache as to how to get money for the day-to-day running of the schools. One representing 3.0\% of them responded that the grant catered for the needs of their schools. Nobody, however, agreed that the grant has brought about increase in levies. On school head revealed that "the capitation has significantly increased school enrolment in basic schools in the Sunyani West District and enables them (head teachers) to buy very urgently needed teaching and learning materials which might not be provided on time by the GES."

Table 6: Reasons for the Construction of the Capitation Grant Percentage Scheme

\begin{tabular}{|l|l|l|}
\hline Responses & Frequency & \\
\hline
\end{tabular}




\begin{tabular}{|l|l|l|}
\hline To support fees & 0 & 0.0 \\
To remove fees & 7 & 16.0 \\
To lessen hardships & 25 & 65.0 \\
To clear financial barriers & 8 & 19.0 \\
Total & $\mathbf{4 0}$ & $\mathbf{1 0 0 . 0}$ \\
\hline
\end{tabular}

It can be seen from Table 6 that more than half $(65.0 \%)$ of the heads indicated that the grant has lessen financial hardships especially of parents, $8(19.0 \%)$ stated that it has helped clear all financial barriers of schools, and $7(16.0 \%)$ of the respondents agreed that the grant was to remove all fees levied on pupils and students. On whether the respondents were given trainings on how to administer the capitation grants, their responses are contained in Table 7.

Table 7: Types of Training given on Capitation Grant

\begin{tabular}{|l|l|c|}
\hline Types & Frequency & Percentage \\
\hline In-service training on capitation grant & 28 & 70.0 \\
Training on school administration & 5 & 12.0 \\
Management of schools & 5 & 12.0 \\
Caring for the school plant & 2 & 6.0 \\
Total & $\mathbf{4 0}$ & $\mathbf{1 0 0 . 0}$ \\
\hline
\end{tabular}

As shown in Table 7, majority $28(70.0 \%)$ of the identified that they were given in- respondents service training on the implementation of the capitation grant scheme, $5(12.0 \%)$ stated they had in-service training on school administration, and $5(12.0 \%)$ also agreed to have had an in-service training in school management. Two representing 6.0\% of them had training on caring for the school plant. Research Question 2: How do head teachers perceive the implementation of the Scheme in the Sunyani West District? The study attempted to find out how the respondents perceived the capitation grant scheme in the District because the way one perceives phenomena determines the person's attitude towards it. Table 8 summarised their responses on their extent of knowledge on the capitation grant scheme.

Table 8: Extent of Knowledge on Capitation Grant Scheme

\begin{tabular}{|l|l|c|}
\hline Responses & Frequency & Percentage \\
\hline Very high extent & 4 & 10.0 \\
High extent & 34 & 84.0 \\
Low extent & 2 & 6.0 \\
Total & $\mathbf{4 0}$ & $\mathbf{1 0 0 . 0}$ \\
\hline
\end{tabular}

Majority 34 (84.0\%) of the respondents were of the opinion that the knowledge they had acquired invaluable knowledge on the implementation of the scheme. Four of them representing $10.0 \%$ indicated "very high extent," while $2(6.0 \%)$ of the respondents stated that they had low but helpful knowledge on the scheme. They were also asked whether or not the scheme should be continued? From Table 9, the information indicates that overwhelming majority $(96.0 \%)$ of the respondents strongly agreed that the scheme should be made to stay. Two representing $4.0 \%$ of the respondents also agreed.

Table 9: Contribution of Scheme

\begin{tabular}{|l|l|c|}
\hline Response & Frequency & Percentage \\
\hline Agree & 2 & 4.0 \\
Strongly agree & 38 & 96.0 \\
Disagree & 0 & 0.0 \\
Strongly disagree & 0 & 0.0 \\
Total & $\mathbf{4 0}$ & $\mathbf{1 0 0 . 0}$ \\
\hline
\end{tabular}


The study again, sought to find out from the respondents the success that the scheme had chalked up after its introduction in the school.

Table 10: Achievement of the Scheme

\begin{tabular}{|l|c|c|}
\hline Achievement & Frequency & Percentage \\
\hline Pupils now regular in school & 0 & 0.0 \\
School enrolment has increased & 21 & 74.0 \\
Fees abolished & 19 & 26.0 \\
Teachers regular & 0 & 0.0 \\
Total & $\mathbf{4 0}$ & $\mathbf{1 0 0 . 0}$ \\
\hline
\end{tabular}

According to Table 10, the is the indication that the scheme had achieved some successes over the years as 21 representing $74.0 \%$ of the respondents pointed out that with the grant, school enrolment had drastically increased. This finding agrees with the views of UNICEF (2007) reports that the decision to replace school fees with capitation grants has yielded some dividends by impacting positively on many enrolment-related figures during the 2005/06 school year, for example, primary school gross enrolment rose by nearly 10 per cent, bringing total primary enrolment to 92.4 per cent nationwide. Primary net enrolment increased from 62 percent to 69 per cent. Nineteen representing $26.0 \%$ of them also affirmed that the scheme had abolished the payment of school fees. In an interview with a head teacher, he reported that "the scheme had relieved parents of much financial responsibilities towards their wards' basic education." On how the implementation of the scheme could be problem-free, the respondents indicated the following suggestions as summarised in Table 11.

Table 11: Suggestions for Effective Implementation of the Scheme

\begin{tabular}{|l|l|l|}
\hline Suggestions & Frequency & Percentage \\
\hline Early release of funds & 9 & 28.0 \\
Clear school planning & 1 & 4.0 \\
Drawing of school plan & 1 & 4.0 \\
Drawing of SPIP Total & 29 & 64.0 \\
Total & $\mathbf{4 0}$ & $\mathbf{1 0 0 . 0}$ \\
\hline
\end{tabular}

The information in Table 11 showed that more than half $(64.0 \%)$ of the respondents said that drawing of the School Performance Improvement Plan (SPIP) was a major factor that could promote the smooth implementation of the scheme. In the interview, they pointed out that the SPIP was to be followed strictly. Nine representing $28.0 \%$ of them reported that the early release of funds by Government would ensure effective implementation. Others also suggested that every school should have a clear school planning, and the drawing of school plan. In answer to the Research Question 2, it came to the fore that the respondents were overwhelmingly happy with scheme since it had increased school enrolment through the abolishment of school fees. They, therefore, advocated for its continuation. Research Question 3: What challenges are associated with the implementation of the Scheme? The objective here was to find out from the respondents the challenges confronting in the smooth implementation of the capitation grant scheme in the Sunyani West District. Table 12 summarised their responses.

Table 12: Challenges in Implementation of Capitation Grant Scheme

\begin{tabular}{|l|l|l|}
\hline Responses & Frequency & Percentage \\
\hline Abolition of fees & 0 & 0.0 \\
Inadequate funds & 13 & 23.0 \\
High enrolment & 2 & 5.0 \\
Delay in release of grant & 25 & 72.0 \\
Total & $\mathbf{4 0}$ & $\mathbf{1 0 0 . 0}$ \\
\hline
\end{tabular}

Table 12 showed that $25(76.0 \%)$ of the respondents stated that the major problem they faced was the delay in the release of the grant. Thirteen representing $23.0 \%$ of them also indicated the inadequacy of the fund, while $2(5.0 \%)$ said that the increased enrolment of pupils was a challenge. From the interviews, it 
came to light that these challenges made their work extremely difficult as a head teacher said the introduction of the capitation grant scheme is at concept but it has several unaddressed challenges about inadequate funds and unexpected increase in enrolment. Classrooms are not available to accommodate the numbers. In a situation where monies are not release on time, many school activities are left undone.

Other respondent indicated also said "it is not easy to access the grant." It can be concluded that the main problems facing the implementation of the scheme were the delayed release of grant, and inadequate funds. These challenges listed are in sync with those enumerated by GES (2005) that some of the challenges facing the implementation of the capitation grant scheme included increased demand for additional classrooms, and untimely release of funds to districts and schools. On the factors responsible for the challenges stated above, they mentioned bureaucracy, lack of funds, and the abolition of fees among others. Table 13 summarised the details.

Table 13: Causes of Challenges faced by Head teachers

\begin{tabular}{|l|l|l|}
\hline Causes & Frequency & Percentage \\
\hline Bureaucracy in disbursement & 15 & 43.0 \\
Lack of funds & 14 & 41.0 \\
Incorrect school enrolment figure & 2 & 5.0 \\
Abolition of fees & 9 & 11.0 \\
Total & $\mathbf{4 0}$ & $\mathbf{1 0 0 . 0}$ \\
\hline
\end{tabular}

From Table 13, it can be observed that the respondents knew of the causes of the above stated challenges. Fifteen representing $43.0 \%$ of the respondents indicated that one of the causes of the challenges was the bureaucracy in the disbursement of the grant. Fourteen representing $41.0 \%$ of them also stated that lack of funds was responsible for their challenges. Again, $9(11.0 \%)$ responded that the abolition of school fees was also a cause of the challenges, while $2(5.0 \%)$ of them reported blamed the challenges on the incorrectly enrolment figures sent to the Ghana Education Service which always resulted in the meagre grant given them. A respondent said "since no fees are to be collected from the pupils, the inadequate grants are not able to cater for all the school needs." The above findings confirm the position of the Northern Network for Education Development (NNED, 2007) that cumbersome procedure of administering the grant, and the finding of Amofa-Kra (1988) that inadequate fund in administrating the day-to-day running of schools were their main challenges.

\section{Conclusions and Recommendations}

The chapter contains the summary of findings, conclusions drawn from the study and recommendations made for effective and efficient implementation of the capitation grant scheme in basic schools. Again, it presents suggestions for further studies.

\section{Summary}

The research was conducted to find out head teachers' perception of the implementation of the capitation grant scheme in the Sunyani West District of the Brong Ahafo Region. The study specifically focused its attention on addressing the following research questions:

1. How do head teachers construct the concept of Capitation Grant Scheme?

2. How do head teachers perceive the implementation of the Scheme in the Sunyani West District?

3. How has the perception of head teachers influenced the implementation of the Capitation Grant Scheme in their school?

4. What challenges are associated with the implementation of the Scheme?

5. To what extent is the head teacher capable of facing the challenges in implementation of the Capitation Grant Scheme?

The area of the study was the Sunyani West District in the Brong-Ahafo of Ghana. The target population was head teachers in the Sunyani West District. The sample was 40 head teachers. The research instruments used for the study were guide. In design in questionnaire and interview thee questionnaires and interview guide, the research questions and literature were taken into consideration so that only relevant information were solicited. The study reviewed related and relevant literature under the following sub-headings: The Free Compulsory Basic Education (fCUBE), the capitation grant scheme, financing basic education, sources 
of school funds, the concept of financial administration, and the challenges related to financial administration in schools.

All 40 copies of questionnaire given out were retrieved resulting in a $100.0 \%$ retrieval rate, and interview process was also successful. The data was analysed using frequencies and percentages to describe the responses of the head teachers on the various items of the questionnaire and interview guide. Before the study, an introductory letter was obtained from the Director of the Institute for Education Planning and Administration (IEPA). The study used two months to collect data, and another two and half months for data cleansing, entering, analysis and report writing. The study data were analysed using descriptive statistics such as frequencies and percentages. Statistical tables were also drawn using the SPSS and Microsoft Excel and the results were discussed to address the research, questions posed. It emerged that overwhelming majority $(95.0 \%)$ of the respondents were males. The modal age of the respondents was $41-50$ years. Again, half (50.0\%) of them had obtained first degree.

\section{Key Findings}

The following are the major findings that emerged from the study:

1. A large majority $(70.0 \%)$ of the head teachers had an in-depth understanding of the source of capitation grant as being from the Government.

2. To $90.0 \%$ of the respondents, the objective of the scheme was to lessen financial burden on the parents through abolition of school fees.

3. Delayed release of funds $(72.0 \%)$ and inadequate funds $(23.0 \%)$ were identified as key challenges confronting the implementers of the scheme.

4. Adequate and timely release of the grant was suggested for effective implementation of the scheme in all basic schools in the District.

5.

\section{Conclusions}

Based on the findings, the study concluded that:

1. The level understanding of the head teachers on the objectives and sources of the grant enabled them to do their best in the implementation process of the Scheme. This positive perception about the students together with their parents has made them to actively involve all relevant stakeholders in the Scheme process.

2. The contributions of stakeholders like teachers, officers from the District Education Office and the Chairmen of SMCs cannot be underestimated in the preparation of SPIP and the subsequent implementation of the capitation grant scheme in the Sunyani West District.

3. Although some challenges such as late release of grant and the inadequacy of it are thwarting the effective implementation of the scheme, it should not be discontinued.

\section{Recommendations}

From the findings and conclusion drawn from the study, the following recommendations are made:

1. Ghana Education Service should continue to train head teachers in financial management and administration for product use of funds. This will give them the accounting acumen to handle monies.

2. Government should timely release grants to schools so that the school heads will avoid prefinancing of school activities. This can do done by eliminating all bureaucracies in receiving and retiring imprests.

3. The capitation grant should be increased so that there will adequate fund for day -to-day management of basic schools.

4. Enrolment figures must serves as basic for disbursing of the capitation grants.

5. Head teachers must continue to involve relevant stakeholders (e.g. teacher, District Director of Education, budget officers, accountants, auditors and chairman of SMCs in the scheme's implementation processes. This will reduce the tendency for allegations and backbiting among stakeholders.

\section{Suggestions for Further Studies}


Due to resource constraints, the study could not cover all basic schools benefiting from the capitation grant scheme. Therefore, the study suggested that the scope of the study should be expanded to cover many basic schools in the country for more representative conclusions on the successes and challenges of the scheme.

\section{Acknowledgements: Rose Adjei (Mrs), Lawrencia Adjei, Justice Adom-Adjei, Bridgit Adom-Adjei, Herbert Adom-Adjei and Diana Adutwumwaa. \\ References}

[1] Abosi, O. C., \& Brookman-Amissah, J.(1992). Introduction to education Ghana. Accra: Sedco.

[2] Akyeampong, K. (2011).R e (assessing) the impact of school capitation grant on education access in Ghana: Creative pathways to access. Research Monongraph, 71

[3] Amanfo, C. P. (2000). The impact of the FCUBE programme on the new educational reforms. Unpublished seminar paper. Department of Primary Education, University of Cape Coast.

[4] Amofa-Kra, S. (1988). Personnel participation in school financial administration: The case of public boarding secondary school in the Cape Coast Municipality of Ghana. Unpublished M. Phil thesis submitted to Faculty of Education, University of Cape Coast, Cape Coast.

[5] Asante, C. (2011). The Capitation grant: Impact on enrolment of pupils in the basic education schools in Ghana. A case study of some selected Junior High Schools in Sunyani Municipality. CEMBA Thesis submitted to IDL, KNUST, Kumasi.

[6] Babble, E. (1992). The practice of social research (6th ed.). Belmont: Wadsworth Inc.

[7] Best, G. W., \& Khan, J. V. (1995) Research in education (7th edition). USA:Prentice Hall Inc. Commonwealth Secretariat. (1993). Better schools resource material for heads. London: Commonwealth Secretariat.

[8] CRIQPEG. (1996). Centre for research into improving quality primary education in Ghana: Phase 2 study report. Cape Coast: University of Cape Coast Printing Press.

[9] CWIQ. (2003). National summary. Accra: Ghana Statistical Service.

[10] Effah, P. (2003). Ghana. In D. Teffera \& P. G. Altbach, (Eds.), African higher education: An international reference handbook (pp. 338' 349). Bloomington, IN: Indiana University.

[11] Fraenkel, J., \& Wallen, N. E. (2000). How to design and evaluate research in education (4th ed.). San Francisco: McGraw Hill Companies.

[12] Ghana Education Service [GES]. (2005). Guidelines for the distribution and utilization of capitation grant to basic schools. Accra: CRDD.

[13] Ghana Education Service [GES]. (2003). Guidelines for the distribution and utilisation of capitation Grant to primary schools. Accra: Ghana Education Service.

[14] Gill, J., \& Johnson, P. (1991). Research methods for managers. London: Paul Chapman Publishing Ltd.

[15] GNA(2006, January 30). Don't undermine capitation scheme. The Daily Graphic, p. 20.

[16] GNECC \& NNED (2006, June 10). Conflicts hampering implementation of capitation grant. Education Agenda, 2, 6-10.

[17] Graham, C. K. (1971). The history of education in Ghana. Accra: Frank Cass and Co. Ltd. Louis, K. S., \& Miles, M. C. (1990). Research on institutionalisation: A reflective review. London: Harcourt Brace.

[18] Korboe, K. \& Boakye, A.(1995). Primary school development project: Report of the Ghana education service for mid-term review. Accra: Ghana Education Service.

[19] Ministry of Education, Science and Sports. MOESS (2005). Linking ESP and the white paper reform. Accra: MOESS.

[20] Mitchell, M. L., \& Jolley, J. M. (2004). Research design explained (5th ed.). Toronto: Wadsworth/Thompson Learning.

[21] Narh-Saam, T. (2004). Financial records keeping of heads of basic schools in the Birim SouthDistrict. Unpublished document dissertation, UEW-Kumasi.

[22] NNED. (2007). NGO commends achievements in education sector. Accra: Ghana News.

[23] Nyarko, H. (2006, February 10). Nine school head teachers reinstated. The Ghanaian Times p. 1

[24] Obeng, P. (2004). Problems of managing finances at Antoa Senior Secondary School. Unpublished document, UEW-Kumasi. 
[25] Osei, R. D., Owusu, G. A., Asem, F. E. \& Afutu-Kotey, R. L. (2009). Effects of outcomes in Ghana. Accra: Institute of capitation grant on education Statistical Social and Economic Research..

[26] Osuala, E. C. (1992). Introduction to research methodology. Onitsha: African- FED Publishers.

[27] Peli, M. (1995). Social Science research methods: a handbook for Africa. (2 ${ }^{\text {nd }}$ ed) Nairobi: East Africa Education Publishers Ltd.

[28] Raffa, R. C.(2003). Handout 3. London: Level of Service.

[29] Salamoat, S. B. (2007) Financial administration practices in public secondary schools in the Accra Metropolis. Unpublished dissertation submitted to Faculty of Education, University of Cape Coast, Cape Coast.

[30] SEND Ghana. (2010, June 30). Some schools still charge fees despite capitation grant. Accra: GNA.

[31] Wortman, C. B., Loftus, E. F. \& Marshall, M. E. (1992). Psychology (4th ed.). New York: McGrawHill Inc. 